Fifth International Conference on Sustainable Construction Materials and

Technologies. http://www.claisse.info/Proceedings.htm

\title{
FLY ASH FROM FLUIDIZED BED COMBUSTION OF PEAT AND WOOD AS A CEMENT REPLACEMENT MATERIAL
}

\author{
Jouni Rissanen $^{\text {a*}}$, Katja Ohenoja ${ }^{\text {a }}$, Mirco Marcellini ${ }^{\text {b }}$, Mirja Illikainen ${ }^{\text {a }}$ \\ ${ }^{\text {a }}$ Fibre and Particle Engineering research unit, Faculty of Technology, University of Oulu, \\ P.O. Box 4300, 90014 Oulu, Finland \\ ${ }^{\mathrm{b}}$ Department of Materials, Environmental Sciences and Urban Planning - SIMAU, \\ Università Politecnica delle Marche, UdR INSTM, 60131 Ancona, Italy
}

*Email: jouni.rissanen@oulu.fi

\begin{abstract}
Fly ash from fluidized bed combustion of peat and wood is a promising material for partial cement replacement. Experiments conducted on mortars in which $20 \%$ of the cement was replaced with fluidized bed combustion fly ash (FBCFA) revealed that 28-day compressive strength can be almost as high as for reference samples in which cement was not replaced is possible to reach. FBCFA in cement can also produce higher compressive strength as coal fly ash and significantly higher strength than limestone filler. FBCFA can decrease the workability of fresh mortar due to its highly irregular particle shape, however, if ash is milled, it could be used even without an additional superplasticizer. The effect of FBCFA on chemical durability and sulfate attack resistance of mortar did not differ significantly from those of coal fly ash and limestone filler.
\end{abstract}

Keywords: Fly ash, fluidized bed combustion, peat, wood, mortar, cement, compressive strength, limestone filler.

\section{INTRODUCTION}

Fluidized bed combustion (FBC) is an efficient, environmentally friendly, and commonly used combustion method. Unlike the traditionally used pulverized coal combustion (PCC) technology, FBC produces less SOx and NOx emissions because of its lower burning temperature (Gulyurtlu et al., 2013a; Hyppänen and Raiko, 2002) and in situ capturing of 
$\mathrm{SO}_{2}$ via direct reaction with Ca-based sorbents during the firing process (Gulyurtlu et al., 2013b; Iisa et al., 2002). In addition, FBC technology can utilize a mixture of low-grade fuels that have a fluctuating quality, composition, and moisture content (Hyppänen and Raiko, 2002; Leckner, 2013; Nowak and Mirek, 2013), which creates challenges to utilizing produced fly ash, since variations in fuel composition leads to variation in fly ash quality. On the other hand, since the cement industry has been pressured to decrease $\mathrm{CO}_{2}$ emissions, various industrial side streams that could be used for cement substitution have been studied intensively.

PCC fly ash as a cement replacement material is already widely studied and has been adopted by the concrete industry to partially replace cement produced from traditional raw materials. However, since the energy industry is continually increasing the use of renewable energy sources (e.g., biomass and wastes), it is reasonable to study fly ashes originating from the combustion of these fuels.

The use of fluidized bed combustion fly ash (FBCFA) as a cement replacement material is one promising way to utilize these fly ashes. They can have pozzolanic (Li et al., 2012; Sata et al., 2007) or hydraulic (Ohenoja et al., 2016b; Rissanen et al., 2017; Zhao et al., 2015) properties so they react with cement and water. Typically, the particle shape of FBCFA irregular (Chindaprasirt et al., 2011; Li et al., 2012; Ohenoja et al., 2016a; Zhao et al., 2015) compared to the spherical particles of PCC fly ash (Li et al., 2012; Zhao et al., 2015). In addition, there is much variation in chemical composition between different ashes, such as in the case of FBCFAs (Gulyurtlu et al., 2013c; Ohenoja et al., 2018). These factors can have an effect on strength, rheology, porosity, and durability of the concrete. For these reasons, experience gained from utilization of PCC in concrete cannot be applied directly to utilization of FBCFA, and therefore, more research is needed. Additionally, only a few studies have focused on utilization of FBCFAs originating from the cocombustion of peat and wood.

The aim of this study was to examine the effect of $20 \%$ cement replacement using FBCFA originating from co-combustion of peat and wood to workability, compressive strength, chemical durability, and sulfate resistance of mortars.

\section{MATERIALS}

FBCFA used in this study originated from a power plant that burned a mixture of peat and wood residues in a fluidized bed boiler. In order to improve the quality of ash, FBCFA was milled (M-FBCFA) using a laboratory-sized ball mill. Fly ash from pulverized coal combustion (CFA) was used to compare the effect of FBCFA to more conventional replacement material. In addition, non-reactive limestone filler (LF) was used to compare the effect of cement replacement to non-reactive filler. Two different aggregate sands were used. Sand 1 is a CEN-standard sand (Normensand) conforming to cement testing standard EN 196-1. Sand 2 is a commercial sand ranging in size from $0 \mathrm{~mm}$ to $3 \mathrm{~mm}$. Two 
different cement types were used in this study. Cement 1 is a Portland composite cement, type CEM II/B-M (S-LL) 42,5 N. In addition to clinker, Cement 1 contains blast furnace slag and limestone filler. Cement 2 is a Portland limestone cement, type CEM II/A-LL 42,5 R. In addition to clinker, Cement 2 contains limestone filler. All cements conform to cement standard EN 197-1. A polycarboxylate-based superplasticizer (SP) was used in this study to improve the workability of some mortars.

\section{METHODS}

Chemical compositions of materials were determined using the X-ray fluorescence method (XRF). Loss on ignition (LOI) at $950^{\circ} \mathrm{C}$ was determined by thermogravimetric analysis using an automatic drying and ashing system. Particle size distribution of materials was determined using a laser diffraction particle size analyzer. Samples MFBCFA and Cement 1 were measured in dry mode, while other samples were measured in wet mode with 2-propanol.

Six different mortar mixture samples were chosen for this study.

1) Ref. 1 is a reference sample prepared from Cement 1 according to cement testing standard SFS-EN 196.

2) Ref. 2 is another reference sample prepared using Cement 2, and it uses Sand 2 instead of Sand 1. Ref. 2 also contains a small amount of SP.

3) The $20 \%$ FBCFA sample is identical to Ref. 2, but $20 \%$ of the cement was replaced by FBCFA and a higher dosage of SP was used.

4) The $20 \%$ M-FBCFA sample is identical to Ref. 1, but $20 \%$ of the cement was replaced by M-FBCFA.

5) The $20 \%$ CFA sample is identical to Ref. 2 , but $20 \%$ of the cement was replaced by CFA.

6) The $20 \%$ LF sample is also identical to Ref. 2, but $20 \%$ of the cement was replaced by LF.

The data presented in this study originates from experiments conducted in two different research projects, which explains why mix design and sample preparation of Ref. 1 and $20 \%$ M-FBCFA slightly differs from rest of the samples.

Table 1. Mix design of mortar samples

\begin{tabular}{lccccc}
\hline Sample & Cement $^{\mathrm{a}}$ & $\begin{array}{c}\text { Replacement } \\
\text { material }^{\mathrm{a}}\end{array}$ & Water $^{\mathrm{a}}$ & Sand $^{\mathrm{a}}$ & SP $^{\mathrm{b}}$ \\
\hline Ref. 1 & 1 & 0 & 0.50 & 3 & 0.00 \\
Ref. 2 & 1 & 0 & 0.50 & 3 & 0.27
\end{tabular}




\begin{tabular}{lccccc} 
20\% FBCFA & 0.8 & 0.2 & 0.50 & 3.0 & 0.54 \\
$\begin{array}{l}\text { 20\% M- } \\
\text { FBCFA }\end{array}$ & 0.8 & 0.2 & 0.50 & 3.0 & 0.00 \\
$20 \%$ CFA & 0.8 & 0.2 & 0.50 & 3.0 & 0.26 \\
& & & & & \\
$20 \%$ LF & 0.8 & 0.2 & 0.50 & 3.0 & 0.28 \\
\hline $\begin{array}{l}\text { a Mass parts } \\
\text { b \% from mass of powders }\end{array}$ & & & &
\end{tabular}

Samples Ref. 1 and 20\% FBCFA were prepared according to cement testing standard SFSEN 196-1, with slight modifications (preparing samples in normal laboratory conditions). The rest of the samples were prepared in bigger batches, and mixing was done in a bucket with a mixer that was attached to a drill. In these samples, mixing time was from four to six minutes. After demolding, samples Ref. 1 and 20\% M-FBCFA were cured in water for 28 days. The rest of the samples were wrapped in plastic after demolding. After seven days, the samples were removed from plastic and were exposed to a relative humidity of $65 \% \pm 5 \%$. The curing of the specimens was conducted at a temperature of $20^{\circ} \mathrm{C} \pm 1^{\circ} \mathrm{C}$. Compressive strengths of mortars were measured after 28 days of curing. Compressive strengths are presented as relative strengths that is the strength of the sample as a percentage of the reference sample's strength.

Workability of mortars was evaluated using the spread table method that is described in mortar testing standard SFS-EN 1015-3. Samples Ref. 2, 20\% FBCFA, 20\% CFA, and 20\% LF were measured using different machines than samples Ref. 1 and 20\% MFBCFA. This machine had been slightly modified and did not totally conform to standard.

Sulfate attack resistance of mortars was studied by partially immersing (to a depth of 40 $\mathrm{mm}$ ) mortar prisms in a $\mathrm{Na}_{2} \mathrm{SO}_{4}$ solution (14 wt. \% aqueous solution) for 21 days. The level of solution was kept constant by adding de-ionized water to replace evaporated water. Two prisms were immersed in a $\mathrm{Na}_{2} \mathrm{SO}_{4}$ solution, and one prism, as a reference, was immersed in de-ionized water. Evaluation of resistance against sulfate attack was based on visual observations of samples.

A dynamic tank leaching test was performed for samples Ref. 2, 20\% FBCFA, 20\% CFA, and $20 \%$ LF. For this experiment, cylindrical mortar samples (height: $40 \mathrm{~mm}$, diameter: $34 \mathrm{~mm}$ ) were prepared using recipes presented in Table 1, however, the sample size was smaller and mixing was done manually. The leaching test was started 39 days after the preparation of samples. During the experiment, samples were kept in water that was saturated with $\mathrm{CO}_{2}$ to simulate the effect of acidic water. Solid to liquid volume ratio was 1:5. $\mathrm{CO}_{2}$-saturated water was renewed to drive the leaching process. The first water of the test was changed after two hours, and the next water was changed after eight hours. Rest 
times were at 24, 48, 72, 102, 168, and 348 hours. Each leaching solution was collected, and the concentrations of calcium and silicon were analyzed using the inductively coupled plasma (ICP) method.

\section{RESULTS AND DISCUSSION}

\section{Chemical Composition of Materials}

FBCFA was composed mainly of $\mathrm{CaO}, \mathrm{SiO}_{2}, \mathrm{Al}_{2} \mathrm{O}_{3}$, and $\mathrm{FeO}_{3}(\mathrm{Table} 2)$. The sum of $\mathrm{SiO}_{2}$, $\mathrm{Al}_{2} \mathrm{O}_{3}$, and $\mathrm{FeO}_{3}$ is $68.5 \%$, which was only slightly lower than $70 \%$, which is the requirement for fly ash standard EN 450-1. Similarly, the main components of CFA were $\mathrm{CaO}, \mathrm{SiO}_{2}, \mathrm{Al}_{2} \mathrm{O}_{3}$, and $\mathrm{FeO}_{3}$. However, the $\mathrm{CaO}$ content of CFA was significantly higher than in FBCFA. Also, the amount of Fe was lower in CFA than in FBCFA. The sum of $\mathrm{SiO}_{2}, \mathrm{Al}_{2} \mathrm{O}_{3}$, and $\mathrm{FeO}_{3}$ was $49 \%$. The amount of $\mathrm{MgO}$ and $\mathrm{SO}_{3}$ was quite low in both ashes. FBCFA also contained some alkalis and phosphate, but the contents of both were below the limits of EN 450-1. Loss on ignition was low in both ashes, which indicates that the amount of unburned carbon was low. It can be concluded that in regards to chemical composition, both ashes are suitable for use as cement replacement material.

LF was mainly composed of $\mathrm{CaO}$ as expected. Chemical compositions of both cements were typical, and there was not much difference between the two. Sand 1 was composed mainly of $\mathrm{SiO}_{2}$, while Sand 2 was composed of $\mathrm{CaO}$ and $\mathrm{SiO}_{2}$.

Table 2. Chemical composition of materials

\begin{tabular}{lccccccc}
\hline $\begin{array}{l}\text { Chemical } \\
\text { composition }\end{array}$ & FBCFA & CFA & LF & Cement 1 & Cement 2 & Sand 1 & Sand 2 \\
\hline $\mathrm{CaO}$ & 16.3 & 42.6 & 97.5 & 58.4 & 65.5 & 0.1 & 79.8 \\
$\mathrm{SiO}_{2}$ & 41.8 & 33.4 & 0.2 & 21.7 & 19.1 & 97.2 & 17.8 \\
$\mathrm{Al}_{2} \mathrm{O}_{3}$ & 13.1 & 10.1 & 0.1 & 5.4 & 5.0 & 1.3 & 0.8 \\
$\mathrm{Fe}_{2} \mathrm{O}_{3}$ & 13.6 & 5.5 & 0.1 & 3.3 & 2.5 & 0.4 & 0.4 \\
$\mathrm{Na}_{2} \mathrm{O}$ & 2.1 & 0.8 & 0.0 & 0.6 & 0.4 & 0.2 & 0.0 \\
$\mathrm{~K}_{2} \mathrm{O}$ & 2.3 & 1.2 & 0.0 & 0.7 & 0.9 & 0.5 & 0.3 \\
$\mathrm{MgO}$ & 2.5 & 2.0 & 1.0 & 3.9 & 1.3 & 0.1 & 0.6 \\
$\mathrm{P}_{2} \mathrm{O}_{5}$ & 3.5 & 0.3 & 0.0 & 0.1 & 0.3 & 0.0 & 0.1 \\
$\mathrm{TiO}_{2}$ & 0.5 & 0.5 & 0.0 & 0.6 & 0.2 & 0.1 & 0.0 \\
$\mathrm{SO}_{3}$ & 2.1 & 1.9 & 0.2 & 3.5 & 3.5 & 0.0 & 0.1 \\
$\mathrm{Cl}$ & 0.1 & 0.0 & 0.0 & 0.1 & 0.1 & 0.1 & 0.0
\end{tabular}




\begin{tabular}{llllllll}
$\begin{array}{l}\text { Loss on ignition 950 } \\
\mathrm{C}^{\circ}\end{array}$ & 0.3 & 2.9 & 44.0 & 3.4 & 5.2 & 0.3 & 6.2 \\
\hline
\end{tabular}

\section{Particle Size Distribution of Cement and Cement Replacement Materials}

The particle size distribution of cement and cement replacement materials is presented in Figures 1a and b. Milling clearly decreased the median particle size (D50) of FBCFA from the original $52.8 \mu \mathrm{m}$ to $10.7 \mu \mathrm{m}$. Median particle sizes of other fine materials were in the same range: CFA: $10.4 \mu \mathrm{m}$, LF: $6.1 \mu \mathrm{m}$, Cement 1: $10.3 \mu \mathrm{m}$, and Cement 2: $10.2 \mu \mathrm{m}$.
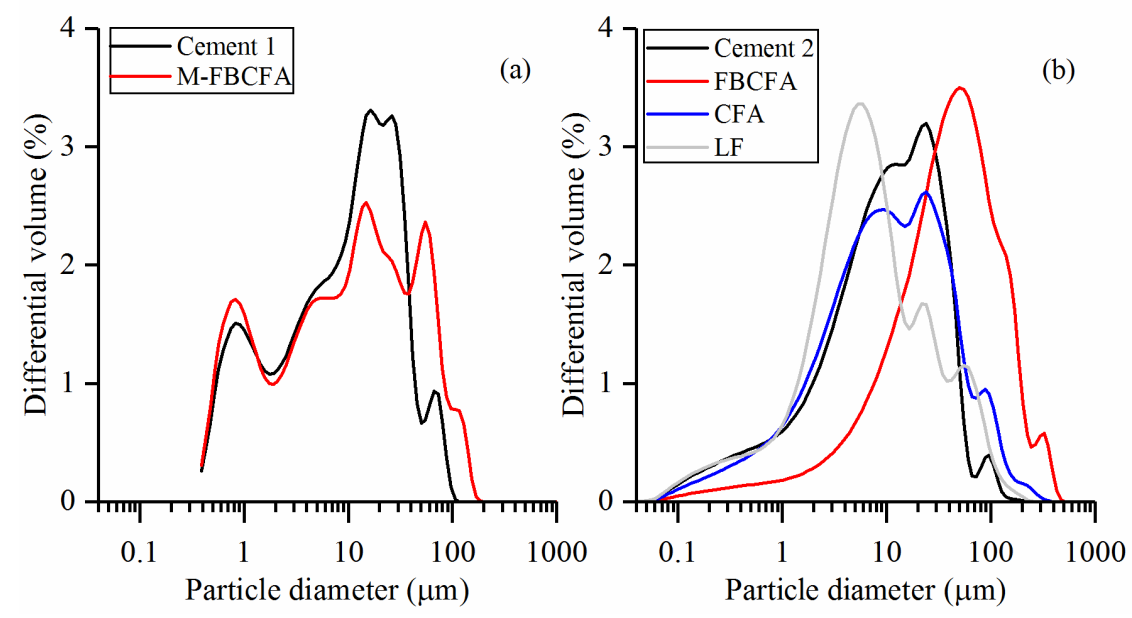

Figure 1. Differential particle size distribution of materials: (a) samples measured in dry mode, (b) samples measured in wet mode

\section{Workability of Mortars}

Experiments done with mortars having 20\% milled or un-milled FBCFA revealed that although this ash increased the water demand and superplasticizer dosage, it can still be used to prepare mortars with good workability if the superplasticizer dosage is sufficient.

Milling of fly ashes can lower the water requirement as several studies have shown (Fu et al., 2008; Li et al., 2012; Rissanen et al., 2018). In this study, milling was not enough to totally prevent the decrease of workability caused by FBCFA. However, after the milling, FBCFA had such a low effect on workability that additional water or superplasticizer was not needed. 
CFA and LF did not have much effect on workability of mortars with a $20 \%$ replacement rate. Approximately the same amount of SP was needed to achieve similar workability with the reference sample.

Table 3. Workability of mortars

\begin{tabular}{lccc}
\hline Sample & $\begin{array}{c}\text { Spread of } \\
\text { sample }\end{array}$ & $\begin{array}{c}\text { Spread of } \\
\text { reference } \\
\text { sample }\end{array}$ & $\begin{array}{c}\text { SP of sample/ } \\
\text { SP of } \\
\text { reference } \\
\text { sample }\end{array}$ \\
\hline $\begin{array}{l}\text { 20\% FBCFA } \\
\text { 20\% M- }\end{array}$ & 11.6 & 12.0 & 2.01 \\
FBCFA & 15.8 & 16.9 & - \\
$20 \%$ CFA & 11.2 & 12.0 & 1.15 \\
$20 \%$ LF & 13.3 & 12.0 & 1.08 \\
\hline
\end{tabular}

\section{Mechanical Strength}

When $20 \%$ of the cement was replaced by un-milled and milled FBCFA, samples reached $79 \%$ and $92 \%$ relative strength, respectively (Figure 2). The 20\% CFA sample reached $82 \%$ relative strength, while the $20 \%$ LF sample reached only $68 \%$ relative strength. It seems that at a $20 \%$ replacement rate, un-milled fly ash can have a similar effect on 28 day mechanical strength as CFA. Additionally, these results could suggest that milling of FBCFA can improve the quality of BFCFA by improving the reactivity of fly ash, resulting in an even higher 28-day strength than with CFA. Same phenomena has been reported also for FBCFAs originating from coal combustion (Li et al., 2012; Zhao et al., 2015). It should be noted, however, that the better performance of $20 \%$ M-FBCFA could be also related to slightly different mortar composition and preparation method. Further studies should be conducted to gain better understanding about the effects of milling of FBCFAs originating from peat and biomass combustion. Both FBCFA and CFA outperformed the unreactive LF, showing that both ashes form reaction products that are beneficial to mechanical properties.

The relative strength of 20\% FBCFAand 20\% M-FBCFA were slightly higher compared to study of Rajamma et al. (2009) in which cement was replaced using FBCFA combustion of forest wastes resulting to $72 \%$ relative strength. With same replacement rate Sheng et al, (2007) reached $87 \%$ and $101 \%$ relative strengths for mortars including FBCFAs form co-combustion FBCFA from coal and petroleum coke, while Sata et al. (2007) achieved approximately $114 \%$ relative strength for concretes in which $20 \%$ of cement was replaced using FBCFA from coal combustion. 


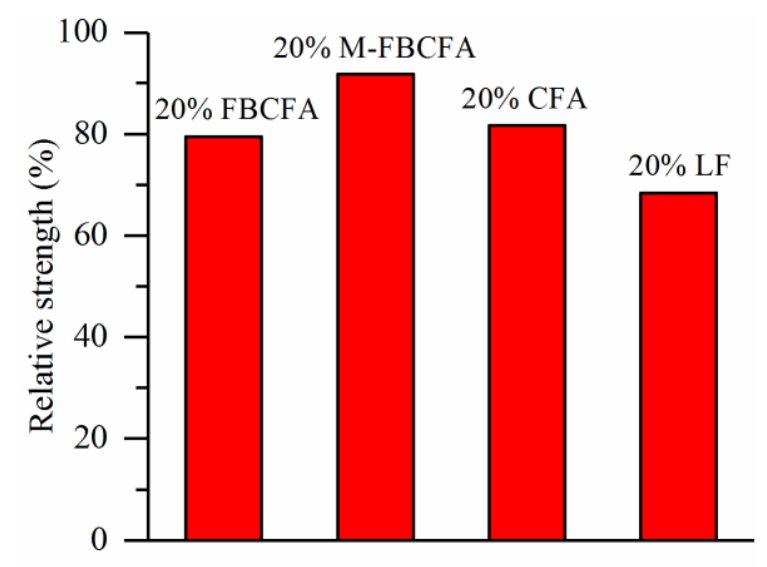

Figure 2. Relative compressive strength of mortars

Without further studies, it is difficult to estimate if the reaction products result from hydraulic or pozzolanic reactions. Ohenoja et al. (2016a, 2016b) have shown that FBCFAs can produce significant compressive strength reacting only with water, which suggests hydraulic properties, while some studies have reported FBCFAs which have pozzolanic properties (Li et al., 2012; Sata et al., 2007). Coal fly ash from pulverized combustion is usually thought to have pozzolanic properties due to high amounts of amorphous silica, but it is known that these ashes can have also hydraulic properties if they contain enough reactive calcium containing phases. The high content of $\mathrm{SiO}_{2}, \mathrm{Al}_{2} \mathrm{O}_{3}$, and $\mathrm{FeO}_{3}$ in studied FBCFA suggest that it could have pozzolanic properties while CFA could possess hydraulic properties due to its high $\mathrm{CaO}$ content.

\section{Chemical Durability of Materials}

Mortar chemical durability was evaluated by examining the leaching of calcium and silicon in acidic water. Calcium and silicon were chosen since the main hydration products of cement are composed mainly from these elements.

It is possible to deduce the dominant leaching mechanism from the results of the tank leaching test by fitting a line to data in which the leaching rate $\mathrm{J}$ (meq $\mathrm{m}^{-2} \mathrm{sec}$ ) is plotted over time (s) in a log/log-scale. The dominant leaching mechanism can be obtained from the slope of that line. If the slope is 0 , it indicates continuous dissolution of the binder matrix. If the slope is -1 , it indicates a wash-off of the surface. If the slope is -0.5 , it indicates that diffusion is the dominant leaching mechanism. (Monosi et al., 2016)

When leaching of calcium is observed, there are some differences in the slopes indicating that there could be some differences in leaching mechanisms as well. There were not many differences in the slopes of Ref. 2, 20\% CFA, and 20\% LF (Figure 3 and Table 4). The 
slopes of these specimens were slightly lower than 0.5 , which could indicate that although diffusion was probably the most dominant leaching mechanism, there could also be some dissolution of calcium containing phases. The slope of $20 \%$ FBCFA indicated that the diffusion was the most dominant leaching mechanism (Figure 3 a and Table 4). When the cumulative amount of leached calcium during the experiment is compared (Table 4), it can be seen that there are no dramatic differences between the samples. Cumulative concentration of calcium leached from 20\% FBCFA was slightly higher than in Ref. 2. It is possible that incorporation of FBCFA has slightly increased the porosity of mortars, which could explain the higher amount of leached calcium.

In the case of leached silicon, the behavior of mortar samples is even more uniform. The most dominant leaching mechanism seems to be diffusion for every sample, and the differences in the cumulative amounts of leached silicon are even lower (Figure $3 \mathrm{~b}$ and Table 4).

Table 4. Slope, coefficient of determination $\left(\mathrm{R}^{2}\right)$ of the linear regression, and cumulative concentration for leaching of calcium and silicon

\begin{tabular}{lccccccc}
\hline & \multicolumn{3}{c}{ Calcium } & & \multicolumn{3}{c}{ Silicon } \\
\cline { 2 - 4 } \cline { 6 - 8 } Sample & Slope & $\mathrm{R}^{2}$ & $\begin{array}{c}\text { Cumulative } \\
\text { concentration } \\
(\mathrm{mg} / \mathrm{L})\end{array}$ & & & & $\begin{array}{c}\text { Cumulative } \\
\text { concentration } \\
(\mathrm{mg} / \mathrm{L})\end{array}$ \\
\hline Ref. 2 & -0.44 & 0.95 & 1181 & & -0.52 & 0.98 & 115 \\
$20 \%$ & & & & & & & \\
FBCFA & -0.55 & 0.98 & 1341 & & -0.55 & 0.97 & 112 \\
$20 \%$ CFA & -0.39 & 0.9 & 1190 & & -0.51 & 0.97 & 126 \\
$20 \%$ LF & -0.41 & 0.9 & 1105 & & -0.53 & 0.98 & 115 \\
\hline
\end{tabular}



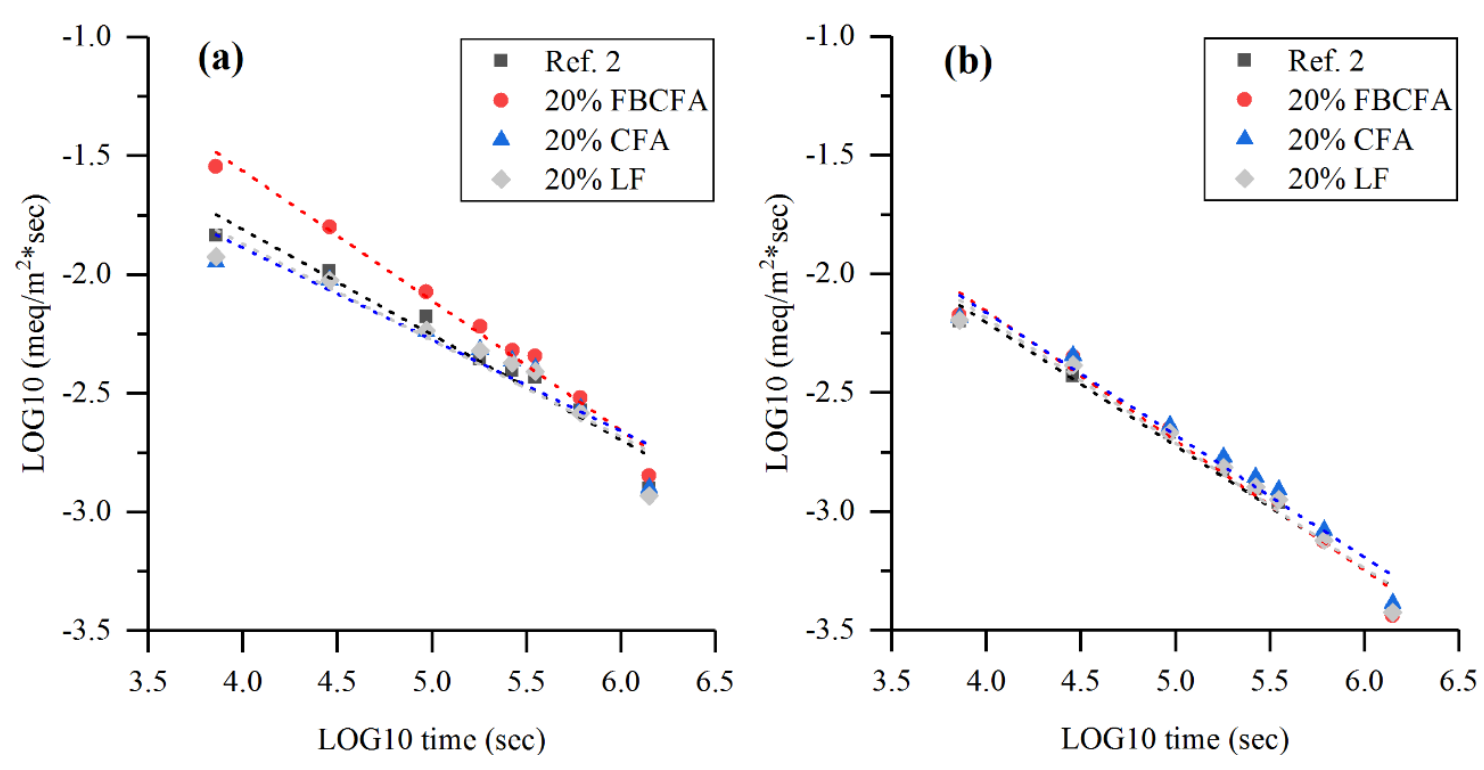

Figure 3. Leaching rate $\mathbf{J}$ of (a) calcium and (b) silicon plotted over time

According to our knowledge, leachability of mortars or concretes containing fly ashes from combustion of peat or co-combustion of peat and wood has not been studied before. Some studies address leaching behavior of concretes or mortars containing fly ashes from fluidized bed combustion (Barbosa et al., 2011, 2013; Tosti et al., 2018), but these studies focused mainly on leaching of heavy metals and other detrimental elements. However, Barbosa et al. $(2011,2013)$ reported that compared to reference concrete, leaching of $\mathrm{Ca}$ was lower in concrete in which $30 \%$ of the cement was replaced by fly ash and $18 \%$ of aggregate was replaced by bottom ash. Both fly ash and bottom ash originated from fluidized bed combustion of bark and forest residues.

\section{Resistance to Sulfate Attack}

It is known that sodium sulfate can react with free calcium hydroxide to form gypsum that can then react with aluminates present in material (Hewlett, 2003). Products formed in these reactions have larger volume than their precursors. This expansion can further damage the material.

Approximately the same levels of efflorescence were observed in every specimen that was immersed in $\mathrm{Na}_{2} \mathrm{SO}_{3}$ solution (Figure 3). All mortar specimens that were immersed in water showed no sign of efflorescence. Apparently, at the replacement rate of $20 \%$, used filler materials did not significantly change the chemistry of mortars so that it would have an effect to efflorescence caused by $\mathrm{Na}_{2} \mathrm{SO}_{3}$ solution. Although pozzolanic materials are reported to improve the sulfate attack resistance of cementitious materials (Hossain et al., 2016), in this case, studied cement replacement probably did not have much effect on the 
content of free calcium hydroxide or aluminates. Additionally, replacement materials did not induce any reactive phases that could react with soluble sulfates to form additional efflorescence. Also the mechanical properties of specimens remained at levels where they were able to resist the pressure caused by sulfate attack.

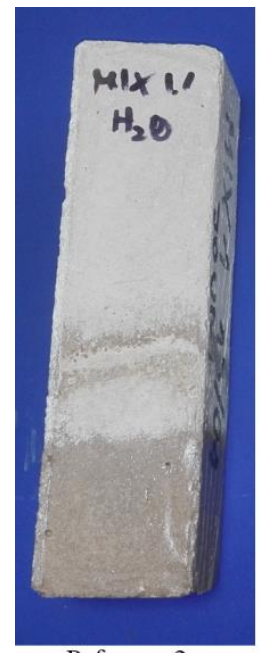

Reference 2

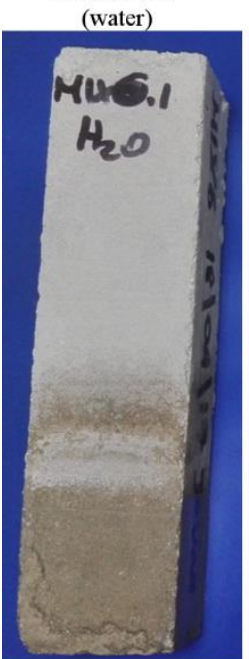

CFA

(water)

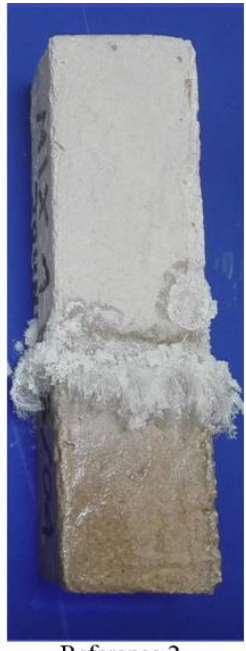

Reference 2

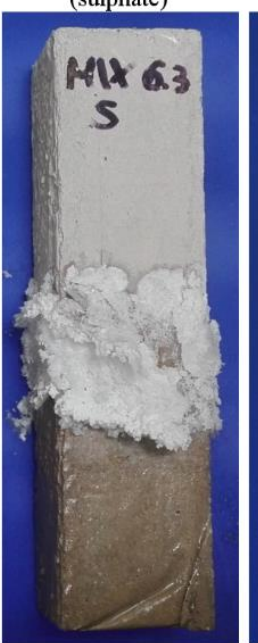

CFA

(sulphate)

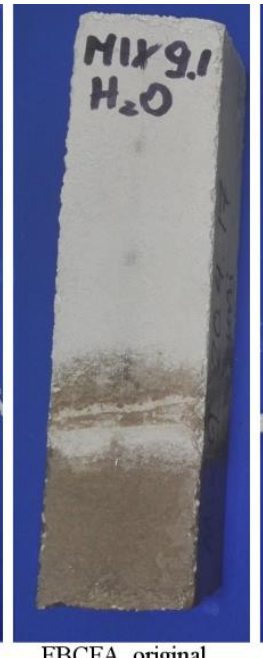

FBCFA, original

(water)

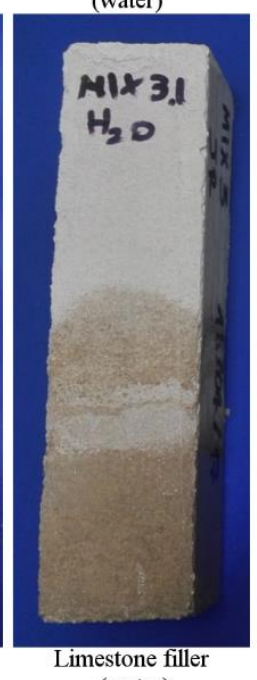

(water)

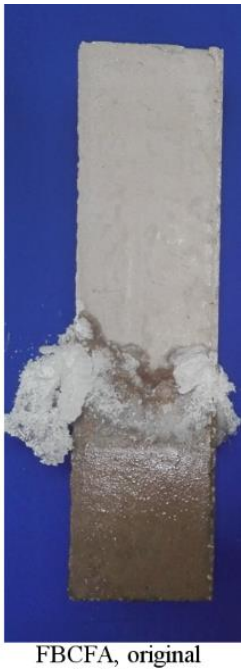

(sulphate)

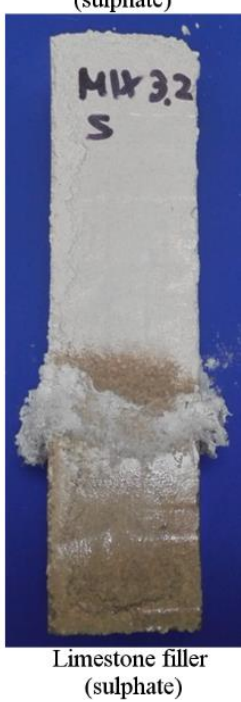

Figure 4. Mortar samples after 21 day sulfate attack experiment

These results are in well-eccondance with literature. FBCFA from wood combustion caused no significant decrease in sulfate attack resistance when the replacement rate was $40 \%$ or lower (Modolo et al. (2018)). Chi and Huang (2014) showed that cement replacement by combination of PCC and FBCFA can increase the strength of the concrete specimen during the sulfate attack experiment. It should be noted, however, that the 
chemical composition of FBCFA (used by Chi and Huang, 2014) was totally different, consisting mainly of $\mathrm{CaO}$ and $\mathrm{SO}_{3}$, compared to ash used in the present study.

\section{CONCLUSIONS}

FBCFA originating from the combustion of peat and wood is a promising material to reduce the amount of cement in mortar and concrete. Utilization of this material would reduce the amount of landfilled fly ash and the environmental impacts of concrete production. At a moderate replacement rate of $20 \%$, the effect of FBCFA on mechanical properties of mortar is similar to that of CFA and both fly ashes outperformed the unreactive LF. Although unmilled FBCFA had an adverse effect on workability of mortar, it was possible to prepare good quality mortar with sufficient SP dosage. Without milling, FBCFA increases the superplasticizer dosage, but if material is milled, it has only a minimal impact on workability. FBCFA and other replacement materials have no significant effect on chemical durability or sulfate attack resistance of mortars, when a $20 \%$ replacement rate is used.

\section{ACKNOWLEDGEMENTS}

Financial support from the ARCTIC-ecocrete project, which is supported by Interreg Nord EU-program and Regional Council of Lapland, is acknowledged. Jouni Rissanen gratefully acknowledges financial support also from the Fortum Foundation and Tauno Tönning's Foundation. Professor Francesca Tittarelli is acknowledged for her contribution to the research plan. Professor Maria Letizia Ruello and Dr. Chiara Giosuè are acknowledged for their contributions to the research plan and laboratory work. Ms. Roberta Marchetti, Mr. Roberto Mancini, Mr. Jani Österlund, and Mr. Jarno Karvonen are acknowledged for their contributions to the laboratory work.

\section{REFERENCES}

Barbosa, R., Lapa, N., Dias, D., Mendes, B., 2013. Concretes containing biomass ashes: Mechanical, chemical, and ecotoxic performances. Constr. Build. Mater. 48, 457-463. https://doi.org/10.1016/j.conbuildmat.2013.07.031

Barbosa, R., Lapa, N., Lopes, H., Gulyurtlu, I., Mendes, B., 2011.

Stabilization/solidification of fly ashes and concrete production from bottom and circulating ashes produced in a power plant working under mono and cocombustion conditions. Waste Manag. 31, 2009-2019. https://doi.org/10.1016/j.wasman.2011.04.020 
Chi, M.C., Huang, R., 2014. Durability performance of concrete containing CFBC fly ash and coal-fired fly ash. Appl. Mech. Mater. 627, 283-287. https://doi.org/10.4028/www.scientific.net/AMM.627.283

Chindaprasirt, P., Rattanasak, U., Jaturapitakkul, C., 2011. Utilization of fly ash blends from pulverized coal and fluidized bed combustions in geopolymeric materials. Cem. Concr. Compos. 33, 55-60. https://doi.org/10.1016/j.cemconcomp.2010.09.017

Fu, X., Li, Q., Zhai, J., Sheng, G., Li, F., 2008. The physical-chemical characterization of mechanically-treated CFBC fly ash. Cem. Concr. Compos. 30, 220-226. https://doi.org/10.1016/j.cemconcomp.2007.08.006

Gulyurtlu, I., Pinto, F., Abelha, P., Lopes, H., Crujeira, A.T., 2013a. 9 - Pollutant emissions and their control in fluidised bed combustion and gasification, in: Scala, F. (Ed.), Fluidized Bed Technologies for Near-Zero Emission Combustion and Gasification, Woodhead Publishing Series in Energy. Woodhead Publishing, pp. 435-480.

Gulyurtlu, I., Pinto, F., Abelha, P., Lopes, H., Crujeira, A.T., 2013b. 9 - Pollutant emissions and their control in fluidised bed combustion and gasification, in: Scala, F. (Ed.), Fluidized Bed Technologies for Near-Zero Emission Combustion and Gasification, Woodhead Publishing Series in Energy. Woodhead Publishing, pp. 435-480.

Gulyurtlu, I., Pinto, F., Abelha, P., Lopes, H., Crujeira, A.T., 2013c. 9 - Pollutant emissions and their control in fluidised bed combustion and gasification, in: Scala, F. (Ed.), Fluidized Bed Technologies for Near-Zero Emission Combustion and Gasification, Woodhead Publishing Series in Energy. Woodhead Publishing, pp. 435-480.

Hewlett, P., 2003. Lea's Chemistry of Cement and Concrete. Elsevier.

Hossain, M.M., Karim, M.R., Hasan, M., Hossain, M.K., Zain, M.F.M., 2016. Durability of mortar and concrete made up of pozzolans as a partial replacement of cement: A review. Constr. Build. Mater. 116, 128-140. https://doi.org/10.1016/j.conbuildmat.2016.04.147

Hyppänen, T., Raiko, R., 2002. Leijupoltto, in: Raiko, R., Sastamoinen, J., Hupa, M., Kurki-Suonio, I. (Eds.), Poltto Ja Palaminen. International Flame Research Foundation, Suomen kansallinen osasto, Jyväskylä.

Iisa, K., Yrjas, P., Kilpinen, P., 2002. Rikin oksidien muodostuminen ja poistaminen, in: Raiko, R., Sastamoinen, J., Hupa, M., Kurki-Suonio, I. (Eds.), Poltto Ja Palaminen. International Flame Research Foundation, Suomen kansallinen osasto, Jyväskylä.

Leckner, B., 2013. 14 - Atmospheric (non-circulating) fluidized bed (FB) combustion, in: Scala, F. (Ed.), Fluidized Bed Technologies for Near-Zero Emission Combustion and Gasification, Woodhead Publishing Series in Energy. Woodhead Publishing, pp. 641-668.

Li, X., Chen, Q., Huang, K., Ma, B., Wu, B., 2012. Cementitious properties and hydration mechanism of circulating fluidized bed combustion (CFBC) 
desulfurization ashes. Constr. Build. Mater. 36, 182-187.

https://doi.org/10.1016/j.conbuildmat.2012.05.017

Modolo, R.C.E., Senff, L., Ferreira, V.M., Tarelho, L.A.C., Moraes, C.A.M., 2018. Fly ash from biomass combustion as replacement raw material and its influence on the mortars durability. J. Mater. Cycles Waste Manag. 20, 1006-1015. https://doi.org/10.1007/s10163-017-0662-9

Monosi, S., Ruello, M.L., Sani, D., 2016. Electric arc furnace slag as natural aggregate replacement in concrete production. Cem. Concr. Compos. 66, 66-72. https://doi.org/10.1016/j.cemconcomp.2015.10.004

Nowak, W., Mirek, P., 2013. 16 - Circulating fluidized bed combustion (CFBC), in: Scala, F. (Ed.), Fluidized Bed Technologies for Near-Zero Emission Combustion and Gasification, Woodhead Publishing Series in Energy. Woodhead Publishing, pp. 701-764.

Ohenoja, K., Tanskanen, P., Peltosaari, O., Wigren, V., Österbacka, J., Illikainen, M., 2016a. Effect of particle size distribution on the self-hardening property of biomass-peat fly ash from a bubbling fluidized bed combustion. Fuel Process. Technol. 148, 60-66. https://doi.org/10.1016/j.fuproc.2016.02.023

Ohenoja, K., Tanskanen, P., Wigren, V., Kinnunen, P., Körkkö, M., Peltosaari, O., Österbacka, J., Illikainen, M., 2016b. Self-hardening of fly ashes from a bubbling fluidized bed combustion of peat, forest industry residuals, and wastes. Fuel. https://doi.org/10.1016/j.fuel.2015.10.093

Ohenoja, K., Wigren, V., Österbacka, J., Illikainen, M., 2018. Applicability of Fly Ash from Fluidized Bed Combustion of Peat, Wood, or Wastes to Concrete. Waste Biomass Valorization. https://doi.org/10.1007/s12649-018-0319-5

Rajamma, R., Ball, R.J., Tarelho, L.A.C., Allen, G.C., Labrincha, J.A., Ferreira, V.M., 2009. Characterisation and use of biomass fly ash in cement-based materials. J. Hazard. Mater. 172, 1049-1060. https://doi.org/10.1016/j.jhazmat.2009.07.109

Rissanen, J., Ohenoja, K., Kinnunen, P., Illikainen, M., 2017. Partial replacement of portland-composite cement by fluidized bed combustion fly ash. J. Mater. Civ. Eng. 29. https://doi.org/10.1061/(ASCE)MT.1943-5533.0001899

Rissanen, J., Ohenoja, K., Kinnunen, P., Romagnoli, M., Illikainen, M., 2018. Milling of peat-wood fly ash: Effect on water demand of mortar and rheology of cement paste. Constr. Build. Mater. 180, 143-153. https://doi.org/10.1016/j.conbuildmat.2018.05.014

Sata, V., Jaturapitakkul, C., Kiattikomol, K., 2007. Influence of pozzolan from various by-product materials on mechanical properties of high-strength concrete. Constr. Build. Mater. 21, 1589-1598. https://doi.org/10.1016/j.conbuildmat.2005.09.011

SFS-EN 1015-11:en. Methods of test for mortar for masonary. Part 11: Determination of flexural and compressive strength of hardened mortar, 1999.

SFS-EN 1015-3:en. Methods of test for mortar for masonry. Part 3: Determination of consistence of fresh mortar (by flow table), 1999.

SFS-EN 196-1:2016:en. Methods of testing cement. Part 1: Determination of strength, 2016. 
SFS-EN 197-1:en. Cement. Part 1: Composition, specifications and conformity criteria for common cements, 2012.

SFS-EN 450-1:2012:en. Fly ash for concrete - Part 1: Definition, specifications and conformity criteria, 2017.

Tosti, L., van Zomeren, A., Pels, J.R., Comans, R.N.J., 2018. Technical and environmental performance of lower carbon footprint cement mortars containing biomass fly ash as a secondary cementitious material. Resour. Conserv. Recycl. 134, 25-33. https://doi.org/10.1016/j.resconrec.2018.03.004

Zhao, J., Wang, D., Liao, S., 2015. Effect of mechanical grinding on physical and chemical characteristics of circulating fluidized bed fly ash from coal gangue power plant. Constr. Build. Mater. 101, Part 1, 851-860. https://doi.org/10.1016/j.conbuildmat.2015.10.144 